\title{
Analisis Kinerja Keuangan Perusahaan Perbankan yang Terdaftar di BEI pada Masa Pandemi Covid-19
}

\author{
Maristiana $\mathrm{Ayu}^{1 *}{ }^{*}$, Ani Pujiati ${ }^{1}$, Ade Sandra Dewi ${ }^{1}$, Novi $^{1}$ \\ ${ }^{1}$ Universitas Sang Bumi Ruwa Jurai \\ *Correspondence : maristiana2017@gmail.com
}

\begin{abstract}
Abstrak.
Tujuan penelitian ini adalah untuk menganalisis kinerja perusahaan perbankan yang terdaftar di BEI pada masa Covid-19. Populasi dalam penelitian ini adalah seluruh perusahaan perbankan yang terdaftar di Bursa Efek Indonesia periode 2018-2020 berjumlah 40 perusahaan, sampel dalam penelitian ini adalah 34 perusahaan. Metode pengambilan data yang dilakukan dalam penelitian ini adalah secara purposive sampling. Hasil penelitian menunjukkan bahwa kepemilikan institusional minimum pada PT Nusantara Inti Corpora, dan kepemilikan institusional maksimum pada PT HM Sampoerna, sedangkan standar. Kepemilikan manajerial minimum yaitu PT Indomobil Sukses International, kepemilikan manajerial maksimum yaitu PT Nipress. Kinerja perusahaan minimum yaitu PT Nusantara Inti Corpora, dan kinerja perusahaan maksimum yaitu PT Astra Otoparts.
\end{abstract}

Kata kunci: BEI, Kinerja Keuangan, Perusahaan Perbankan

\begin{abstract}
.
The purpose of this study was to analyze the performance of banking companies listed on the IDX during the Covid-19 period. The population in this study were all banking companies listed on the Indonesia Stock Exchange for the 2018-2020 period totaling 40 companies, the sample in this study was 34 companies. The data collection method used in this study was purposive sampling. The results showed that the minimum institutional ownership at PT Nusantara Inti Corpora, and the maximum institutional ownership at PT HM Sampoerna, while the standard. Minimum managerial ownership is PT Indomobil Sukses International, maximum managerial ownership is PT Nipress. The minimum company performance is PT Nusantara Inti Corpora, and the maximum company performance is PT Astra Otoparts.
\end{abstract}

Keywords: IDX, Financial Performance, Banking Companies

\section{PENDAHULUAN}

Kinerja keuangan menjadi suatu penilaian yang mendasar mengenai bentuk yang dipunyai suatu perusahaan. Investor dalam berinvestasi memikirkan beberapa hal yang bersangkutan dengan informasi yang dapat mereka gunakan sebagai dasar keputusan investasi, diantaranya adalah mengenai kinerja keuangan perusahaan. Baik buruknya kinerja keuangan yang dipunyai oleh perusahaan dapat diamati dari laporan keuangannya (Putri \& Sutra Dewi, 2019).

Resiko likuiditas sangat berpengaruh khususnya untuk bank-bank yang memiliki sumber pendanaan terbatas dan kurang stabil. Bisnis perbankan sangat terkait erat dengan penerapan Good Corporate Governance atau tata kelola perusahaan yang baik, hal ini dapat dilihat dari visi dan misi perbankan yang menjadikan Good Corporate Governance sebagai salah satu misi yang ingin dicapai perbankan. Good Corporate Governanceberfokus pada mengatur arah resiko yang benar dan melindungi seluruh kepentingan stakeholders. Selain itu, bisnis perbankan berlandaskan pada kepercayaan nasabah sehingga penerapan Good Corporate Governance menjadi faktor penting dalam memelihara kepercayaan nasabah, 
pemegang saham dan para pemangku kepentingan lainnya (Masitoh \& Hidayah, 2018).

Dengan adanya pandemi Covid-19 ini menyebabkan Fluktuasi saham yng berdampak pada perilaku investor dalam berinvestasi di pasar modal (Muti'ah \& Anwar, 2021). Hal ini membuat kekhawatiran dari para investor dan menjadi tantangan tersendiri bagi perusahaan untuk menjaga kepercayaan investor yang memiliki nilai tersendiri karena kapasitasnya yang dapat dimanfaatkan untuk menciptakan stabilitas ekonomi nasional (Korniawan, 2016). Kepercayaan investor harus senantiasa dipertahankan oleh perusahaan demi keberlangsungan perusahaan itu sendiri, sehingga perusahaan bisa bertahan dalam keadaan pandemi ini.

Kinerja keuangan bank merupakan bagian dari kinerja bank secara keseluruhan (Tanor et al., 2015). Kinerja bank secara keseluruhan merupakan gambaran prestasi yang dicapai bank dalam operasionalnya baik menyangkut aspek keuangan, pemasaran, penghimpunan dan penyaluran dana, teknologi maupun sumber daya manusia (Tatengkeng \& Tangkuman, 2015). Kinerja keuangan adalah suatu analisis yang dilakukan untuk melihat sejauh mana suatu perusahaan telah melaksanakan dengan menggunakan aturan-aturan pelaksanaan keuangan secara baik dan benar (Tumandung et al., 2017).

Kinerja keuangan adalah gambaran tentang setiap hasil ekonomi yang mampu diraih oleh perusahaan perbankan pada saat periode tertentu melalui aktifitas-aktifitas perusahaan untuk menghasilkan keuntungan secara efisien dan efektif, yang dapat diukur perkembangannya dengan mengadakan analisis terhadap data-data keuangan yang tercermin dalam laporan keuangan (Pagiu \& Pundissing, 2020). Untuk mengukur sebuah keberhasilan perusahaan pada umumnya berfokus pada laporan keuangan disamping data-data non keuangan lain sebagai penunjang (Jonathan, 2018). Informasi kinerja bermanfaat untuk memprediksi kapasitas perusahaan dalam menghasilkan arus kas dan sumber dana yang ada. Pengukuran kinerja keuangan dilakukan bersamaan dengan proses analisis. Analisis kinerja keuangan merupakan proses pengkajian secara kritis terhadap review data, mengukur, menghitung, mengiterprestasi, dan memberikan solusi terhadap keuangan pada suatu periode tertentu (Ulfa \& Asyik, 2020).

Tujuan penilaian kinerja keuangan yaitu untuk mengetahui keberhasilan pengelolaan keuangan perusahaan terutama kondisi likuiditas, kecukupan modal, dan profitabiitas yang di capai dalam tahun berjalan maupun tahun sebelumnya; serta untuk mengetahui kemampuan perusahaan dalam mendayagunakan semua asset yang dimiliki dalam menghasilkan profit secara efisien (Dewa \& Sitohang, 2015).

Kinerja keuangan bank sangat tergantung pada kegagalan atau keberhasilan yang diraih dari kegiatan operasionalnya. Jika kegiatan operasionalnya baik maka kinerja keuangan akan berhasil dan sebaliknya. Kinerja keuangan bank dapat diukur menggunakan salah satu analisis yaitu analisis rasio keuangan (Tanor et al., 2015).

Analisis rasio keuangan merupakan kegiatan membandingkan angka-angka yang ada dalam laporan keuangan dengan cara membagi satu angka dengan angka yang lainnya (Rahmah \& Komariah, 2016). Perbandingan dapat dilakukan antara satu komponen dengan komponen dalam satu laporan keuangan atau antar komponen yang ada di antara laporan keuangan. Rasio keuangan merupakan suatu perhitungan rasio dengan menggunakan laporan keuangan yang berfungsi sebagai alat ukur dalam menilai kondisi keuangan dan kinerja perusahaan. Rasio keuangan adalah angka yang diperoleh dari hasil perbandingan satu pos laporan keuangan dengan pos lainnya yang mempunyai hubungan yang relevan dan signifikan (Trianto, 2017). Perbandingan dapat dilakukan antara satu pos dengan pos lainnya dalam satu laporan 
keuangan atau antar pos yang ada di antara laporan keuangan (Hutapea et al., 2017)

\section{METODE PENELITIAN}

Populasi dalam penelitian ini adalah seluruh perusahaan perbankan yang terdaftar di Bursa Efek Indonesia periode 2018-2020, berdasarkan data dari BEI pada tahun 20182020 populasi perusahaan perbankan sebanyak 40 perusahaan perbankan. Metode pengambilan data yang dilakukan dalam penelitian ini adalah secara purposive sampling sehingga didapat 34 perusahaan sebagai berikut:

Tabel 1. Perusahaan Perbankan yang terdaftar di Bursa Efek Indonesia periode 2018-2020

\begin{tabular}{cll}
\hline No & Kode & \multicolumn{1}{c}{ Nama Emiten } \\
\hline 1 & AGRO & Bank Rakyat Indonesia \\
Agroniaga Tbk \\
2 & AGRS & Bank IBK Indonesia, Tbk \\
3 & ARTO & Bank Artos Indonesia Tbk \\
4 & BABP & Bank MNC Internasional Tbk \\
5 & BACA & Bank Capital Indonesia Tbk \\
6 & BBCA & Bank Central Asia Tbk \\
7 & BBHI & Bank Harda Internasional Tbk \\
8 & BBMD & Bank Mestika Dharma Tbk \\
9 & BBNI & Bank Negara Indonesia \\
& & (Persero) Tbk \\
10 & BBTN & Bank Tabungan Negara \\
11 & BBYB & Bank Yudha Bhakti Tbk \\
12 & BCIC & Bank J Trust Indonesia Tbk \\
13 & BDMN & Bank Danamon Indonesia Tbk \\
14 & BEKS & Bank Pembangunan Daerah \\
15 & BGTB & Banten Tbk \\
16 & BINA & Bank Ganesha Tbk Perdana Tbk \\
\hline
\end{tabular}

\begin{tabular}{|c|c|c|}
\hline 17 & BJBR & $\begin{array}{l}\text { Bank Pembangunan Daerah } \\
\text { Jawa Barat Tbk }\end{array}$ \\
\hline 18 & BJTM & $\begin{array}{l}\text { Bank Pembangunan Daerah } \\
\text { Jawa Timur Tbk }\end{array}$ \\
\hline 19 & BKSW & Bank QNB Indonesia Tbk \\
\hline 20 & BMAS & Bank Maspion Indonesia Tbk \\
\hline 21 & BMRI & Bank Mandiri (Persero) Tbk \\
\hline 22 & BNBA & Bank Bumi Arta Tbk \\
\hline 23 & BNII & Bank Maybank Indonesia Tbk \\
\hline 24 & BNLI & Bank Permata Tbk \\
\hline 25 & BSIM & Bank Sinar Mas Tbk \\
\hline 26 & BSWD & Bank of India Indonesia Tbk \\
\hline 27 & BTPN & Bank BTPN Tbk \\
\hline 28 & DNAR & Bank Oke Indonesia Tbk \\
\hline 29 & INPC & $\begin{array}{l}\text { Bank Artha Graha Internasional } \\
\text { Tbk }\end{array}$ \\
\hline 30 & MAYA & $\begin{array}{l}\text { Bank Mayapada Internasional } \\
\text { Tbk }\end{array}$ \\
\hline 31 & NISP & Bank OCBC NISP Tbk \\
\hline 32 & NOBU & Bank Nationalnobu Tbk \\
\hline 33 & PNBN & Bank Pan Indonesia Tbk \\
\hline 34 & SDRA & $\begin{array}{l}\text { Bank Woori Saudara Indonesia } \\
1906 \text { Tbk }\end{array}$ \\
\hline
\end{tabular}

Variabel yang diukur dalam Kinerja Keuangan adalah berdasarkan Return on Asset (ROA), Return on Equity (ROE), Non Performing Loan (NPL), dan Capital Aequancy Ratio (CAR) pada masing-masing periode waktu. Analisis dilakukan dengan melihat dan membandingkan nilai min, max, mean, dan std. deviasi.

\section{HASIL DAN PEMBAHASAN}

Variabel-variabel yang digunakan dalam penelitian ini meliputi ROA, ROE, CAR, dan NPL akan diuji secara deskriptif seperti berikut ini :

Tabel 2. Hasil Uji Statistik Deskriptif Descriptive Statistics

\begin{tabular}{lrrrrr}
\hline & N & \multicolumn{1}{c}{ Min } & \multicolumn{1}{c}{ Max } & \multicolumn{1}{c}{ Mean } & \multicolumn{1}{c}{$\begin{array}{c}\text { Std. } \\
\text { Deviation }\end{array}$} \\
\hline ROA & 34 & $-29,92$ & 73,11 & 3,2874 & 14,19061 \\
ROE & 34 & $-126,67$ & 53,30 & 5,2768 & 40,27526 \\
CAR & 34 &, 77 & 256,27 & 74,0426 & 42,10978 \\
NPL & 34 & 1,40 & 14,22 & 6,1308 & 3,40952 \\
Valid N (listwise) & 34 & & & & \\
\hline
\end{tabular}

Berdasarkan analisis, menunjukkan minimum sebesar $-29,92$ dan ROA bahwa mean dari ROA sebesar 3,2874, ROA maksimum sebesar 73,11 sedangkan standar 
deviasi ROA sebesar 14,19061. Berdasarkan analisis, menunnjukkan bahwa mean dari ukuran ROE sebesar 5,2768, ukuran ROE minimum sebesar -126,67yaitu dan ROE direksi maksimum sebesar 55.30 sedangkan standar deviasi ukuran dewan direksi sebesar 3,40952.

Berdasarkan analisis data menunjukkan bahwa mean dari kepemilikan institusional sebesar 73.8291, kepemilikan institusional minimum sebesar 35.00 yaitu PT Nusantara Inti Corpora, dan kepemilikan institusional maksimum sebesar 98.00 yaitu PT HM Sampoerna, sedangkan standar deviasi kepemilikan institusional sebesar 15.94299.

Berdasarkan analisis menunjukkan bahwa mean dari kepemilikan manajerial sebesar 3.3510, kepemilikan manajerial minimum sebesar 0.00 yaitu PT Indomobil Sukses International, kepemilikan manajerial maksimum sebesar 24.42 yaitu PT Nipress, sedangkan standar deviasi kepemilikan manajerial sebesar 5.35515. 61 2. Variabel Dependen a. Kinerja Perusahaan Berdasarkan analisis data pada table 4.3 menunjukkan bahwa mean dari kinerja perusahaan sebesar 1.1056, dan kinerja perusahaan minimum sebesar 0.22 yaitu PT Nusantara Inti Corpora, dan kinerja perusahaan maksimum sebesar 2.73 yaitu PT Astra Otoparts, sedangkan standar deviasi dari kinerja perusahaan sebesar 0 . 51059.

\section{KESIMPULAN}

Kepemilikan Manajerial menunjukkan bahwa mean dari kepemilikan manajerial sebesar 3.3510, kepemilikan manajerial minimum sebesar 0.00 yaitu PT Indomobil Sukses International, kepemilikan manajerial maksimum sebesar 24.42 yaitu PT Nipress, sedangkan standar deviasi kepemilikan manajerial sebesar 5.35515. 61 2. Variabel Dependen a. Kinerja Perusahaan Berdasarkan analisis data pada table 4.3 menunjukkan bahwa mean dari kinerja perusahaan sebesar 1.1056, dan kinerja perusahaan minimum sebesar 0.22 yaitu PT
Nusantara Inti Corpora, dan kinerja perusahaan maksimum sebesar 2.73 yaitu PT Astra Otoparts, sedangkan standar deviasi dari kinerja perusahaan sebesar 0 . 51059.

\section{DAFTAR PUSTAKA}

Dewa, A. P., \& Sitohang, S. (2015). ANALISIS KINERJA KEUANGAN PT INDOFOOD SUKSES MAKMUR TBK DI BURSA EFEK INDONESIA. Jurnal Ilmu Dan Riset Manajemen, 4(3).

https://doi.org/10.29264/jkin.v14i1.24 44

Hutapea, A. W., Saerang, I. S., \& Tulung, J. E. (2017). Pengaruh Return On Asset, Net Profit Margin, Debt to Equity Ratio dan Total Aset Turnover Terhadap Harga Saham Industri Otomotif Dan Komponen Yang Terdaftar di Bursa Efek Indonesia. Jurnal EMBA, 5(2), 541-552.

Jonathan, I. B. (2018). Pengaruh Struktur Modal, Ukuran Perusahaan, Pertumbuhan Perusahaan Terhadap Kinerja Keuangan Pada Perusahaan Non Keuangan Dengan Menggunakan Dupont System. Jurnal Muara Ilmu Ekonomi Dan Bisnis, 2(2), 424-432. https://doi.org/10.24912/jmieb.v2i2.1 610

Korniawan, R. (2016). Menjaga Kepercayaan Investor Melalui Kasus Tax Evasion Apple Inc. Di Irlandia: Literature Review. Jurnal Kajian Wilayah, $\quad 7(2), \quad 87-100$. https://doi.org/10.14203/jkw.v7i2.748 Masitoh, N. S., \& Hidayah, N. (2018). PENGARUH PENERAPAN GOOD CORPORATE GOVERNANCE TERHADAP KINERJA PERUSAHAAN (Studi Empirik Pada Perusahaan Perbankan di BEI tahun 2014 - 2016). TEKUN: Jurnal Telaah Akuntansi Dan Bisnis, 9(1), 49-59. https://doi.org/10.22441/tekun.v8i1.2 596 
Muti'ah, A., \& Anwar, M. (2021). NALISIS PERBEDAAN ABNORMAL RETURN SEBELUM DAN SESUDAH PENGUMUMAN COVID-19 SEBAGAI PANDEMI GLOBAL OLEH WHO (Studi pada Pasar Modal Negara-Negara ASEAN). Jurnal Ilmiah Akuntansi Dan Keuangan, 4(1), 236-245.

Pagiu, C., \& Pundissing, R. (2020). PENGARUH

KINERJA KEUANGAN TERHADAP HARGA SAHAM PADA P.T. HANJAYA MANDALA SAMPOERNA, Tbk. Jurnal Economix, 8(1), 115-126.

Putri, A. D., \& Sutra Dewi, A. (2019). Pengaruh Corporate Governance Dan Leverage Terhadap Kinerja Keuangan Pada Perbankan Yang Terdaftar Di Bei. $1-14$. https://doi.org/10.37301/jkaa.v0i0.53 87

Rahmah, M. N., \& Komariah, E. (2016). Analisis Laporan Keuangan dalam Menilai Kinerja Keuangan Industri Semen yang Terdaftar di BEI (Studi Kasus PT Indocement Tunggal Prakarsa TBK). Jurnal Online Insan Akuntan, 1(1), 43-58.

Tanor, M. O., Sabijono, H., \& Walandouw, S. K. (2015). Analisis Laporan Keuangan Dalam Mengukur Kinerja Keuangan Pada PT. Bank Artha Graha Internasional, Tbk. Jurnal Ekonomi Dan Bisnis, 3(3), 639-649.

Tatengkeng, V., \& Tangkuman, S. (2015). Analisis Kinerja Laporan Keuangan Pt. Bank Sulut (Persero) Tbk Periode 2009-2013 Tahun. Jurnal Riset Ekonomi, Manajemen, Bisnis Dan Akuntansi, 3(1), 145-152. https://doi.org/10.35794/emba.v3i1.6 674

Trianto, A. (2017). Analisis Laporan Keuangan Sebagai Alat Untuk Menilai Kinerja Keuangan Perusahaan Pada Pt. Bukit Asam (Persero) Tbk Tanjung Enim. JURNAL ILMIAH EKONOMI GLOBAL MASA KINI, 8(3).
Tumandung, C., Murni, S., \& Baramuli, D. (2017). Analisis Pengaruh Kinerja Keuangan terhadap Harga Saham pada Perusahaan Makanan dan Minuman yang Terdaftar di Bei Periode 2011 2015. Jurnal Riset Ekonomi, Manajemen, Bisnis Dan Akuntansi, 5(2), 1728-1737.

Ulfa, R., \& Asyik, N. F. (2020). Pengaruh Kinerja Keuangan Terhadap Nilai Perusahaan Dengan Corporate Governance Sebagai Variabel Moderasi. International Journal of Social Science and Business, 4(2). https://doi.org/10.23887/ijssb.v4i2.24 229 